\title{
Sinergisme Nilai, Fungsi, dan Harapan pada Sikap Positif Berbahasa
}

\author{
Abdul Rasyid*) \\ Pos-el: bahasass@indosat.net.id
}

\begin{abstract}
Abstrak
Label kekosongan dari manusia Indonesia terhadap pengetahuan, pandangan, dan perilaku positif terhadap bahasa Indonesia akan menjadi pengantar kiamat bagi bahasa Indonesia karena bertumbuh dan berkembangnya bahasa Indonesia sangat bergantung pada pendukung bahasa Indonesia itu sendiri. Dengan demikian, dalam era kekinian, nilai, fungsi, dan harapan yang terdapat dalam sikap positif berbahasa sebaiknya diformulasikan dalam paradigma sinergisme yang kongkret. Artinya, konsep sikap positif tidak hanya menjadi bagian dari doktrin pembinaan kebahasaan dan anjuran bernasionalisme, tetapi harus menjadi media pemberdayaan yang utama dalam kehidupan bermasyarakat, khususnya dalam hal perilaku berbahasa. Wujud paradigma tersebut adalah konsep yang dapat atau diharapkan menumbuhkan keyakinan, menggugah perasaan, dan mendorong kecenderungan bertindak sehingga sikap positif tidak lagi menjadi sesuatu yang abstrak. Sikap positif adalah kelangsungan, kenyataan, dan kemanfaatan atau konsistensi berbahasa.
\end{abstract}

Kata kunci: sinergisme, fungsi, dan sikap positif bahasa

\section{Pendahuluan}

Dalam era kekinian, sikap positif berbahasa tidak lagi harus dipandang sebagai sesuatu yang instan terjadi atau langsung diterima masyarakat setelah diajukan oleh pembina atau penyuluh bahasa. Namun, yang perlu diperhatikan adalah sikap positif mengandung muatan-muatan dinamis yang membutuhkan formulasi pada tataran penjabaran sehingga ia dapat menjadi sistem yang terpadu.

Hal itu perlu diperhatikan secara sungguh-sungguh karena sikap positif berbahasa merupakan tautan multifungsi dari anggapan,

*) Staf Teknis pada Balai Bahasa Ujung Pandang 
tata nilai, dan perilaku. Smith berpendapat bahwa perangkat penerimaan tentang dunia pengalaman diterjemahkan ke dalam tata nilai yang memberi pedoman tentang sifat selayaknya perikehidupan ini. Tata nilai itu selanjutnya diungkapkan sebagai perangkat sikap yang di dalam perilaku berupa pernyataan putusan penilaian (Moeliono, 1981:143).

Gambaran dan pernyataan tersebut di atas mengisyaratkan bahwa nilai, fungsi, dan harapan dalam sikap positif berbahasa seharusnya diformulasikan dalam paradigma sinergisme yang kongkret. Artinya, konsep sikap positif tidak hanya menjadi bagian dari doktrin pembinaan kebahasaan dan anjuran bernasionalisme, tetapi harus dikemas dalam pola yang runtut sehingga menjadi media pemberdayaan dalam kehidupan bermasyarakat. Wujud paradigma sikap positif berbahasa adalah suatu konsep yang dapat diharapkan menumbuhkan keyakinan, menggugah perasaan, dan mendorong kecenderungan bertindak sehingga sikap positif tidak lagi menjadi sesuatu yang abstrak.

\section{Pembahasan}

\subsection{Strategi Pendekatan}

Manusia dalam kehidupannya selalu dihadapkan dengan objek sikap yang beragam, salah satunya adalah bahasa. Oleh karena itu, kognisi, perasaan, dan kecenderungan bertindak atau tanggapan selalu timbul atau muncul sehingga membentuk suatu sisi pandang. Sisi pandang yang muncul dari seseorang atau sekelompok orang didasari oleh nilai, fungsi, dan harapan dari objek sikap sehingga memandang sikap dapat dilihat sebagai sikap penggerak dan sikap mental. 
Allport (Suhardi, 1996:15) memberikan pengertian tentang sikap sebagai berikut.

(1) Sikap diperoleh dengan cara dipelajari, tidak secara turuntemurun.

(2) Sikap selalu berkaitan dengan objek yang dapat berupa benda kongkret atau pun benda abstrak.

(3) Sikap diperoleh dari pergaulan dengan orang-orang di sekeliling kita, baik melalui perilaku maupun melalui komunikasi verbal.

(4) Sikap selalu mengandung kesiagaan untuk bertindak dengan cara tertentu terhadap objek.

(5) Sikap bersifat efektif, artinya sikap mencakupi perasaan yang dapat terungkap melalui pikiran seseorang terhadap suatu objek, dapat bersikap positif, negatif, atau netral.

(6) Sikap mengandung unsur dimensi waktu, artinya sikap itu dapat sesuai dengan waktu tertentu, tetapi tidak sesuai dengan waktu yang lain.

(7) Sikap mengandung unsur kelangsungan, artinya sikap itu berlangsung lama secara taat asas.

(8) Sikap diketahui melalui penafsiran

Kedelapan pengertian sikap tersebut dapat dipilah menjadi dua kelompok utama, yaitu (1) kelompok sikap yang bermakna sikap motorik atau penggerak dan (2) kelompok sikap yang bermakna sikap mental. Kedua kelompok sikap itu apabila diarahkan dalam konteks sikap positif berbahasa maka ia berfungsi mengatur, mengendalikan, dan mengarahkan tingkah laku pengguna bahasa.

Jika kita menoleh kembali ke perangkat fungsi bahasa yang baku, sikap sepatutnya dipusatkan pada peningkatan sikap kesetiaan 
bahasa, sikap kebanggaan bahasa, dan kesadaran akan norma bahasa (Moeliono, 1981:145). Namun, menurut hemat penulis, kesetiaan, kebanggaan, dan kesadaran bahasa masih dalam tataran sikap mental sehingga memerlukan formulasi yang mengarahkan pengguna bahasa pada sikap motorik atau penggerak. Dalam konsep ini, masalah kebahasaan bukan lagi milik pencinta bahasa Indonesia, melainkan milik penganut paham yang sungguh-sungguh memahami bahwa bahasa Indonesia selalu berada dalam taraf terjunjung.

\subsection{Penataan Sinergisme}

Sikap penutur bahasa kemungkinan tidak mengandung validasi hanya karena informasi tentang sikap positif berbahasa yang sampai kepada mereka tidak cukup. Anjuran bersikap positif baru menyentuh sisi mental dari mereka setelah mendengar atau menerima anjuran itu yang hanya terbatas pada pengakuan. Oleh karena itu, nilai, fungsi, dan harapan dalam sikap positif berbahasa sepatutnya diformulasikan dalam tahap-tahap yang berkelanjutan.

Sinergisme nilai sikap positif berbahasa, fungsi sikap positif berbahasa, dan harapan sikap positif berbahasa adalah kelangsungan, kenyataan, dan kesinambungan sikap mental dan sikap penggerak dalam tataran perilaku berbahasa. Konsep perumusan seperti itu dapat membantu masyarakat atau penutur bahasa memahami dan dapat memanfaatkan nilai sikap positif berbahasa.

Sikap positif berbahasa memiliki beberapa komponen sikap yang membangunnya. Sikap itu bisa dianggap sebagai sejumlah nilai yang dipertimbangkan, yang terdapat pada semua sifat yang dihubungkan dengan objek sikap. Triandis (Suhardi, 1996:22) mengisyaratkan bahwa sikap terdiri atas tiga komponen, yaitu 
komponen kognitif, komponen efektif, dan komponen perilaku. Dengan dasar itu, kita membuat formulasi sinergisme sikap positif berbahasa.

\subsubsection{Nilai Sikap Positif Berbahasa}

Pada tahap ini, sikap positif berbahasa baru dianggap sebagai suatu kumpulan ide, gagasan, atau nilai sehingga komponen sikap yang berperan baru komponen kognitif. Misalnya, sikap terhadap bahasa Indonesia dapat menyertakan atau mencakup pengetahuan Anda mengenai isi Sumpah Pemuda, pengetahuan Anda mengenai sejarah bahasa Indonesia, keyakinan Anda mengenai kedudukan dan fungsi bahasa Indonesia, pengetahuan Anda mengenai kebijakan bahasa Indonesia, dan sebagainya. Pengetahuan yang menyatu dengan diri Anda merupakan kenyakinan berdasarkan penilaian yang mengarah pada kualitas diperlukan atau tidak diperlukan, disukai atau tidak disukai terhadap bahasa Indonesia.

Wujud sikap positif berbahasa dalam tahap ini merupakan suatu kompleks ide-ide, gagasan-gagasan, nilai-nilai, dan normanorma. Fungsi sikap positif berbahasa dalam tahap ini adalah mengatur, mengendalikan, dan memberikan arah kepada penutur bahasa atau sekurang-kurangnya penutur bahasa memiliki pengetahuan tentang bahasa Indonesia.

\subsubsection{Fungsi Sikap Positif Berbahasa}

Pada tahap ini sikap positif berbahasa berkenaan dengan emosi yang berkaitan dengan bahasa tertentu. Bahasa tersebut dirasakan sebagai suatu hal yang menyenangkan atau tidak menyenangkan. 
Pengaruh emosional ini yang memunculkan watak tertentu terhadap sikap penutur, seperti watak termantap, termotivasi, dan tergerak.

Jika Anda penutur bahasa Indonesia, Anda merasa senang dengan upaya-upaya pengembangan dan pembinaan bahasa Indonesia. Anda menyenangi lembaga Pusat Bahasa, Balai Bahasa, dan Kantor Bahasa dan juga sekaligus menjadi lembaga tersebut sebagai tempat bertanya, berdiskusi, atau berkonsultasi mengenai masalah kebahasaan dan kesastraan. Anda menyenangi cara berbicara Bapak Dendy Sugono, Bapak SBY, dan cara berbicara figur-figur lainnya. Anda senang membaca karya tulis yang memakai bahasa Indonesia yang baik dan benar. Anda merasa gusar, risau, atau prihatin ketika seorang pewara mengatakan: "Waktu dan tempat kami persilakan". Anda sangat prihatin ketika mendengar bahwa pada Ujian Akhir Nasional yang lalu banyak murid, pelajar, atau siswa yang tidak lulus pelajaran bahasa Indonesia.

Wujud sikap positif dalam tahap ini adalah suatu bentuk aktivitas dan perilaku berpola dari penutur bahasa. Perilaku berbahasa yang demikian dapat menciptakan atau melahirkan sistem sosial. Dalam sistem sosial tersebut terjadi aktivitas manusia yang berinteraksi, bergaul, atau berhubungan yang satu dengan yang lainnya dan memakai kaidah-kaidah kebahasaan dengan cermat. Vikor (Moeliono, 1981:147) mengatakan bahwa salah satu sikap penutur bahasa menerima pembinaan adalah menerapkan materi pembinaan dengan aktif. Kelompok ini mengidentifikasi dirinya dengan bahasa itu dan merupakan penunjang di dalam pengembangan bahasa. 


\subsubsection{Harapan Sikap Positif Berbahasa}

Setelah mengetahui tahap pengetahuan dan tahap perasaan, yang lebih penting lagi adalah tahap pengharapan. Tahap pengharapan merupakan satu sikap yang mencakup semua kesiapan perilaku berbahasa. Seandainya Anda penutur bahasa memiliki sikap positif terhadap pengembangan dan pembinaan bahasa Indonesia maka Anda akan memuji, membantu, atau mendukung upaya-upaya pembimbingan bahasa dan upaya-upaya pengkodifikasian bahasa.

Dalam tahap ini, sikap positif berbahasa diwujudkan oleh penutur bahasa dalam perilaku kongkret. Artinya, penutur bahasa memanfaatkan sikap nilai positifnya, memanfatkan fungsi sikap positifnya, dan memanfatkan harapan sikap positifnya sehingga secara bertahap penutur bahasa akan menuai sesuatu dari konsistensi berbahasanya.

Agaknya kurang adil menyalahkan penutur bahasa yang tidak mampu menggunakan bahasanya dengan baik dan benar jika di samping itu tidak dikembangkan sistem peransang yang mendorongnya ke arah perbaikan. Ganjaran apa yang dapat diharapkan jika ia mahir berbahasa? Pada zaman Hindia Belanda atau Jepang, kemahiran atau kefasihan berbahasa Belanda atau Jepang dikaitkan dengan peluang memperoleh kenaikan pangkat. Iklan yang menawarkan pekerjaan dengan penghasilan yang cukup tinggi bagi pelamar yang pandai berbahasa Inggris seharusnya menjadi bahan pertimbangan yang serius bagi para penentu garis haluan. Kita dapat menyaksikan para pemuda yang mencari pekerjaan berbondongbondong memasuki kursus bahasa Inggris tanpa disuruh-suruh (Moeliono, 1981:150). 
Saat ini, Pusat Bahasa sementara menggodok satu sistem peransang yang bernama UKBI (Uji Kemahiran Berbahasa Indonesia) dan juga sebagai sarana ukur kemampuan berbahasa atau kemahiran berbahasa yang berstandar nasional.

Kemudian, dalam kebudayaan memang dikenal istilah harapan budaya (cultural expectation), yakni harapan masyarakat dari suatu kebudayaan bagi anggotanya untuk bertingkah laku dan berbuat sesuai dengan norma-norma atau adat istiadat yang berlaku.

Sekadar ilustrasi dari pernyataan di atas.

Laindo sebagai seorang yang dibesarkan dalam 'kebudayaan nasional' diharapkan dapat berperilaku positif terhadap bahasa Indonesia. Namun, suatu ketika Laindo berperilaku, berbuat, atau berbahasa tidak sesuai dengan kaidah-kaidah kebahasaan yang berlaku, maka dia dianggap menyimpang dari nilai, fungsi, dan harapan sikap positif berbahasa atau dianggap menyimpang dari nilai budaya dan sistem sosial yang melingkupinya. Namun, pertanyaan yang perlu dijawab oleh semua peserta seminar, apakah sikap positif berbahasa sudah menjadi bagian dari nilai budaya atau sistem sosial kita?

\section{Penutup dan Saran}

\subsection{Penutup}

Pembinaan dan pengembangan sikap positf berbahasa perlu terus dilanjutkan, bukan hanya yang berkaitan dengan pembinaan dan pengembangan sikap mental melainkan juga pembinaan dan pengembangan sikap motorik atau sikap penggerak. Berdasarkan uraian di atas, sikap positif berbahasa dapat diperkenalkan kepada masyarakat sesuai dengan tahap-tahapnya. 
Tahap pertama, penutur bahasa memiliki pengetahuan tentang bahasa.

Tahap kedua, penutur bahasa memanfaatkan pengetahuan kebahasaannya dalam sistem sosial.

Tahap ketiga, penutur bahasa menjadikan perilaku berbahasa yang baik dan benar sebagai salah satu kenyataan sosial.

Dari tahapan itu, diharapkan muncul sinergisme nilai, fungsi, dan tahapan sikap positif berbahasa atau dengan pengertian lain bahwa kita mengoptimalkan peran sikap positif berbahasa dalam berbagai sektor kehidupan.

Dengan demikian, sikap positif bahasa adalah perbuatan yang didasarkan pada pendirian, pendapat, atau keyakinan yang tegas serta bersifat nyata dan membangun dalam menggunakan bahasa.

\subsection{Saran}

Wahai! Para penyumpah yang mengaku menjunjung bahasa Indonesia, hendaklah engkau memiliki tiga hal yang positif terhadap bahasa Indonesia.

(1) Jika engkau tidak dapat memberikan manfaat pada bahasa Indonesia, janganlah engkau memberikan kerusakan pada bahasa Indonesia.

(2) Jika engkau tidak mau memuji bahasa Indonesia, janganlah engkau menjelek-jelekkannya atau menghinanya

(3) Jika engkau tidak bisa membuat bahasa Indonesia lebih berjaya, janganlah engkau membuatnya tidak bermakna apaapa. 
Akhirnya, mari kita menunjukkan sikap yang benar dan menunjukkan tindakan yang benar kepada penutur bahasa Indonesia, kalau bukan kita siapa lagi.

\section{Daftar Pustaka}

Alwi, Hasan. 2000. Bahasa Indonesia Pemakai dan Pemakaiannya. Jakarta: Pusat Bahasa, Depdiknas.

Astar, Hidayatul dkk. 2003. Pemertahanan Bahasa Cina di Jakarta. Jakarta: Pusat Bahasa. Departemen Pendidikan Nasional.

Krech, David et al. 1996. Sikap Sosial (social Attitudes). Penerjemah: Siti Rachmah dkk. Jakarta: Pusat Pembinaan dan Pengembangan Bahasa, Departemen Pendidikan dan Kebudayaan.

Moeliono, Anton. 1981. Pengembangan dan Pembinaan Bahasa Ancangan Alternatif di dalam Perencanaan Bahasa. Jakarta: Penerbit Djambatan.

Suhardi, Basuki. 1996. Sikap Bahasa. Jakarta: PT Usmawi. 